IN 1897, Mr. E. W. Swanton became curator of the Museum and still holds that office. The founder died in 1913; no provision had been made for its future, and it was taken over by a committee with Sir Archibald Geikie as chairman. From that time to the present, the necessary funds to allow the work to continue have been subscribed year by year chiefly by local residents. As its activities steadily increased, it became more and more desirable that the Museum should be moved to a central position. In 1925 the committee purchased an old house with beautiful grounds in Haslemere High Street; new galleries for the adequate display of the space-for-time schedules were added and the collections removed there in 1926. Afterwards a new gallery was added to contain a valuable gift of British birds. Through grants from the Carnegie United Kingdom Trust, the work has been extended to include a regional and ecological survey of the district. The value of the Museum as a teaching centre is widely known. Every autumn mycology students from the University of Oxford make it their headquarters. A course in field biology held at Whitsun attracted students from a wide area.

\section{Hittites in Northern Syria}

ONCE more Sir Leonard Woolley's archæological investigations in the East have produced unanticipated results. In his dispatch from Atchana in Northern Syria (The Times, June 13), which covers the work of his expedition during the first half of the current season, he records that two hundred inscribed tablets have been found, which reveal for the first time the existence of a strongly established and highly organized Hittite power in Northerm Syria at about 1600 B.c., at least two centuries before the great expansion of the Hittite Empire, centring on Hattusas (Boghaz Keui) beyond the Taurus, in what is now Anatolia, with which scholars were previously familiar from excavation and inscribed records. These archives are part of the official documents removed from the Hittite palace, of which a preliminary examination was made at the close of last year's excavations, and now shown to have been destroyed by fire, presumably accidental, as the contents of the building had been removed. The most striking feature of the building, in the account given by Sir Leonard, is the skilled arrangement and the elaborate character of the accommodation. The ruins, still standing to more than a man's height, cover more than 22,000 square feet. Access to the building is from an open courtyard and through a great entry into an entrance hall, from which doorways right and left give admission to the business and residential quarters of the palace respectively. These were virtually separate buildings without intercommunication, and the difference in their character and arrangement indicate their entirely different purposes. In the residential quarter, intended, Sir Leonard thinks, for important members of the palace personnel-the royal family being accommodated above, and the domestic staff, equipment and stores being housed in the courtyard in front of the entrythe accommodation consisted of suites, each of which contained a good-sized bathroom and lavatory. The whole arrangement and content of the palace is, as Sir Leonard remarks, eloquent of a strong and stable government ; while the pottery, ivory and gold work bear witness to relations with Cyprus, Crete, Phenicia and the Greek mainland, as well as with Egypt and Mesopotamia.

\section{The Unity Schools}

THE fifteenth Unity School was held at Jordans Hostel in Bucks, on May 20-23. The general subject was the need and the relation of philosophy to the social sciences, and an introductory address on that topic was given by Prof. Morris Ginsberg, on the evening of May 20. On May 21, Mr. F. S. Marvin introduced the central subject of "What we mean by Social Justice", and the liveliness of the discussion showed clearly how deeply the current thinking on these questions goes, and how much it needs clarification and, so far as possible, harmonization. Dr. C. H. Desch introduced the question of the comparison of our approach to truth in physical and social science, and Prof. Herbert Dingle gave a parallel statement. In particular the question was raised, and viewed from several angles, of whether it is possible in social science properly to speak of a scientific experiment. On May 22, Prof. J. H. Muirhead gave a carefully prepared and moving discourse on the place of the State in relation to right and justice, with the title, "State Law and Individual Morality". The programme, as originally drawn up, was concluded on the Sunday evening by a historical review by Dr. A. J. Carlyle of the various larger subjects which had occurred in the earlier debates-justice, law, sovereignty and the freedom and equality of men-mainly as they are treated in the codes and writings of Greeks, Roman jurists and medieval thinkers. In view of the great success and obvious usefulness of such gatherings, the possibility of extending them to a larger number of people, more frequent occasions and a still wider expanse of subjects is being considered. Further information on the Unity Schools can be obtained from Mr. F. S. Marvin, Pantiles, Coneydale, Welwyn Garden City, Herts.

\section{Correct Street Lighting}

THE General Electric Co. Ltd. has installed in its street-lighting showroomsat Magnet House, Kingsway, London, W.C.2, a model demonstrating many of the problems that arise in street lighting and how they have been effectively solved by the methods recom mended in the final report on street lighting issued by the Ministry of Transport. The model measures $5 \mathrm{ft}$. long by $2 \mathrm{ft}$. wide, the lighting columns and roads being to a scale of 1 in 380 . Running the whole length of the modes is a main arterial road lighted by columns which in practice would provide a mounting height to light source of $25 \mathrm{ft}$. for a main road (Group $A$ ). The thoroughfare is lighted by a staggered arrangement of units not more than $150 \mathrm{ft}$. apart. In every third position an auxiliary unit is centrally suspended, so that there can be adequate lighting down and across what would otherwise be a dark central section of the road. After a roundabout, 